\title{
Plywood bonding with an adhesive based on tannins from Acacia mangium Wild. bark from trees grown in Northeastern Brazil
}

Jaltiery Bezerra de Souza ${ }^{1} \oplus$, Tatiane Kelly Barbosa de Azevêdo ${ }^{2} \oplus$, Thaís Brito Sousa ${ }^{3}$,

Gualter Guenther Costa da Silva²®, José Benedito Guimarães Júnior ${ }^{3}$, Alexandre Santos Pimenta ${ }^{\circledR} \odot$

\footnotetext{
1 Universidade Federal da Paraíba, Areia, PB, Brasil. E-mail: jaltierytecseg@gmail.com

2 Universidade Federal do Rio Grande do Norte, Macaíba, RN, Brasil. E-mail: tatianekellyengenheira@hotmail.com; gualtermve@gmail.com; alexandre_spimenta@hotmail.com

${ }^{3}$ Universidade Federal de Lavras, Lavras, MG, Brasil. E-mail: thaisbflorestal@gmail.com; jose.guimaraes@deg.ufla.br
}

ABSTRACT: This study evaluated the quality of plywood panels bonded with adhesives produced with tannins from the bark of Acacia mangium Wild. trees and compared their bonding performance with commercial adhesive formulations. Crude hot-water extract from the bark of $A$. mangium was employed to synthesize the adhesive formulation for plywood bonding. Twelve plywood panels with five layers were produced, four with each type of adhesive. Static bending strength, modulus of elasticity, modulus of rupture and Janka hardness were evaluated. Water absorption percentages were determined after immersion for 2 and 24 hours. Regarding mechanical properties, there was no statistical difference among the adhesive based on $A$. mangium and the commercial formulations. However, based on the water absorption results, plywood panels bonded with $A$. mangium tannins were found to be suitable only for indoor uses due to higher absorption compared to the other adhesives.

\section{Colagem de compensados com adesivo à base de taninos de Acacia mangium Wild. cultivada no Nordeste do Brasil}

RESUMO: O presente trabalho teve como objetivo avaliar a qualidade de painéis compensados colados com taninos da casca de Acacia mangium Wild., comparando o desempenho de colagem com dois adesivos comerciais. Extrato bruto da casca de $A$. mangium obtido com água quente foi utilizado na síntese de uma formulação adesiva. Doze painéis compensados de 5 lâminas foram produzidos, quatro painéis por adesivo. A resistência à flexão estática e o módulo de elasticidade foram determinados e também a dureza Janka. Foram obtidas a porcentagem de absorção de água após 2 e 24 horas de imersão. Com relação às propriedades mecânicas, não houve diferença estatística entre 0 adesivo produzido com taninos de $A$. mangium e os adesivos comerciais. Entretanto, tendo como base os resultados de absorção de água, os painéis colados com taninos de $A$. mangium são indicados para uso interno em função da sua alta absorção.

Palavras-chave: propriedades físico-mecânicas; adesivos renováveis; painéis de madeira 


\section{Introduction}

The Brazilian wood products market has experienced significant growth due to the establishment of new factories and modernization of existing ones, along with an efficient forest research program. During the last three decades, issues associated with environmentally friendly products and sustainability of forest activity have driven research in this area. In this respect, the search for wood products made with renewable raw materials has increased considerably (Ösbay \& Ayrilmis, 2015). Within this search, wood adhesives produced from natural substances are of significant relevance, since most of the formulations used for bonding wood products come from fossil resources (Zhou \& Pizzi., 2014). Vegetable tannins, condensed tannins or simply tannins are chemicals composed of polyphenols classified in two types, hydrolysable and condensed. Condensed tannins account for over $90 \%$ of global production (Durval et al., 2017) and henceforth they will be referred to only as tannins.

Tannins are employed in several industrial applications, such as leather tanning, plastic production, oil well drilling, water treatment (Nepomuceno et al., 2018), paint and pharmaceutical manufacture (Carvalho et al., 2018), including fungicides and products to kill cariogenic bacteria (Araújo et al., 2018), and wood adhesive production (Hoong et al., 2011; Zhou \& Pizzi, 2014). Researchers are unanimous in stating that tannin-based adhesives can replace synthetic ones for bonding of wood products. Among the tannins used to synthesize commercial adhesives, those from black wattle (Acacia mearnsii De Wild.) are by far the most popular. In Brazil, the planting of black wattle in large forest stands is restricted to the southern region, where the species is best adapted and satisfactory growth rates are achieved (Hillig et al., 2002). The area planted with black wattle in Brazil is around 170,000 hectares, which makes it the largest producer of the tree in the world (Chan et al., 2015).

Acacia mangium Wild. is native to Malaysia. It and Acacia auriculiformis A. Cunn. ex Benth. are the two most planted species of this genus. Acacia mangium alone is grown on more than 600,000 hectares of planted forests in the world, providing wood as raw material for pulp and paper, low-cost furniture, civil construction, plywood and firewood (IPEF, 2020). The species has fast growth rate, low nutritional requirements and high nitrogen fixation rate, as well as tolerance to acidic soils and compaction, characteristics that result in high production of biomass per hectare and input of nutrients via litter where the tree is grown (Balieiro et al., 2004). For these reasons, the species is recommended for restoration of degraded areas and use for windbreak and shading in agroforestry and other types of forest management systems (IPEF, 2020). In Brazil, the planting of Acacia mangium is expanding steadily due to its good adaptability to the variable edaphoclimatic conditions of the country. However, despite producing good quality wood, Acacia mangium is mainly used as firewood, although it can be employed to produce woodcement boards. Acacia mangium bark contains sufficient tannins to enable the production of adhesives (Hoong et al., 2009), though the content can vary from one planting site to another and with the time of the year the tannins are extracted (Paes et al., 2010). The tannin content in the bark depends on the trees' origin. So, research is needed to define the tannin content in the species' bark according to the growing site and assess the technical feasibility of producing adhesives, since this kind of tannin has recognized acceptance worldwide.

The present study aimed: to evaluate the tannin content in Acacia mangium bark from trees grown in Northeastern Brazil; to assess the technical viability of employing tannins from Acacia mangium bark to produce adhesive formulations for plywood panel bonding; and to compare the bonding performance of Acacia mangium tannins with two types of commercial adhesives, one based on black wattle tannins and the other a phenol-formaldehyde resin.

\section{Materials and Methods}

\section{Trees and bark collection}

Thirty trees were harvested from a four-year-old Acacia mangium plantation (planting spacing of $3.0 \mathrm{~m} \times 2.0 \mathrm{~m}$ ) located in the municipality of Macaíba, Rio Grande do Norte state, Brazil. The local climate has Köppen classification of transition from tropical to dry savannah (transition from As to BSw), with average temperature of $27^{\circ} \mathrm{C}$, maximum of 32 and minimum of $21^{\circ} \mathrm{C}$, average relative humidity of $76 \%$ and annual rainfall varying from 864 to $1,071 \mathrm{~mm}$ (IDEMA, 2013). After harvesting, the trees were debarked and the collected material was stored in plastic bags. Samples were used to determine the moisture content. Then, the material was placed in a climate-controlled room at $25^{\circ} \mathrm{C}$ and relative humidity of $65 \%$ for drying until reaching moisture equilibrium, around 12 - 15\%. After 25 days, the bark was ground in a forage crusher equipped with a $2 \mathrm{~mm}$ sieve.

\section{Tannin extraction and qualification}

For tannin extraction, a proportion (mass/mass) of distilled water and bark equal to 1:10 was employed. The material was placed in a $12 \mathrm{~L}$ stainless-steel pan inside a laboratory autoclave at a temperature of $120^{\circ} \mathrm{C}$ for 1 hour. The extraction was carried out two times for each of 10 bark batches with $1 \mathrm{~kg}$ of dry bark per batch. For all batches, the extract was filtered to eliminate fine particles. The extracts were put together to form a composite sample and then placed in stainlesssteel trays, which were left in a solar oven until complete evaporation of water. After that, the powder was ground with a porcelain mortar and pestle and sieved to granulometry of 60 mesh. This material was used for later formulation of the adhesive. Before evaporation, $50 \mathrm{~mL}$ aliquots of the crude extract were retrieved to determine the total solids content (TSC), Stiasny number (SN) and condensed tannins content (CTC), with four replicates for each parameter.

To measure the CTC, the $50 \mathrm{~mL}$ aliquots of the crude extract were oven dried at $60+2{ }^{\circ} \mathrm{C}$ and their total solids content (TSC) was calculated by using Equation 1. 


$$
\mathrm{TSC}=\left(\frac{\mathrm{M} 1-\mathrm{M} 2}{\mathrm{M} 1}\right) \cdot 100
$$

where: TSC - Total solids content in $50 \mathrm{~mL}$ of crude extract (\%); M1 - initial mass of crude extract (g); M2 - final mass of solids after evaporation (g).

To obtain the total condensed tannins content (TTC), first the Stiasny number was determined in the extracts by the method described by Guangcheng et al. (1991), with four replications. For this, $4 \mathrm{~mL}$ of formaldehyde $(37 \% \mathrm{~m} / \mathrm{m})$ and 1 $\mathrm{mL}$ of concentrated hydrochloric acid were added to $50 \mathrm{~mL}$ of crude extract. The mixture was kept under reflux for $30 \mathrm{~min}$. After this time, the mixture was cooled and filtered and the solids were oven dried at a temperature of $60+2{ }^{\circ} \mathrm{C}$ for $48 \mathrm{~h}$. The dried material was weighed and the Stiasny number was calculated by Equation 2 .

$$
\mathrm{N}=\left(\frac{\mathrm{M} 2}{\mathrm{M} 1}\right) \cdot 100
$$

where: $\mathrm{N}$ - Stiasny number (\%); M1 - mass of solids in 50 $\mathrm{mL}$ of crude extract (g); M2 - mass of tannin-formaldehyde precipitate (g).

With the Stiasny number, the condensed tannins content was calculated by using Equation 3 and is reported as percentage of dry weight of bark.

$$
\mathrm{TTC}=\frac{\mathrm{TST} \cdot \mathrm{I}}{100}
$$

where: CTC - condensed tannins content (\%); TSC - total solids content (\%); N - Stiasny number (\%).

\section{Preparation of the tannin-formaldehyde adhesive} formulation

In a reaction flask, $360 \mathrm{~g}$ of tannins, $40 \mathrm{~g}$ of paraformaldehyde and $400 \mathrm{~mL}$ of distilled water were mixed and heated to $50^{\circ} \mathrm{C}$. Aliquots were taken from time to time to assess the viscosity. The mixture was kept under continuous stirring ( $500 \mathrm{rpm}$ ) until reaching a target viscosity equal to $900 \mathrm{cP}$. The adhesive was synthesized with a predicted final solids content of $50 \%$. The following adhesive properties were determined: $\mathrm{pH}$, viscosity, gel time and solids content. Viscosity was determined with a Brookfield viscometer, according to the procedures described in the ASTM D1084 standard (ASTM, 1997). Gel time was measured in a Marconi MA560 gel timer with a glass tube dipped in glycerin at $120^{\circ} \mathrm{C}$. Solids content was determined according to the procedures of the ASTM D1490-01 standard (ASTM, 2006).

\section{Plywood bonding}

To manufacture the plywood panels, industrial rotary peeled plies of Pinus sp. with dimensions of $300 \mathrm{~mm} x$ $300 \mathrm{~mm} \times 2 \mathrm{~mm}$ (length, width and thickness) were used to compose 5-layer panels with final thickness of $10 \mathrm{~mm}$.
Before this, the wood plies were oven dried until reaching final moisture content of $8 \%$. Only plies without any defects (cracks, knots, stains, etc.) were employed to produce the panels. Twelve panels were manufactured, four with adhesives based on tannins from Acacia mangium bark, four bonded with a commercial adhesive made of tannins from black wattle (Acacia mearnsii) bark (Phenotan ${ }^{\text {TM }} \mathrm{M}$, TANAC, Montenegro, RS, Brazil) and four bonded with a commercial phenol-formaldehyde adhesive (GPC, Curitiba, PR, Brazil). All adhesives were spread on only one side of each cross band in a quantity of $320 \mathrm{~g} \mathrm{~cm}^{-2}$. An assembly time of $15 \mathrm{~min}$ was applied. After assembly, the panels were pressed at $150^{\circ} \mathrm{C}$ for $10 \mathrm{~min}$ in an electrically heated hydraulic press at a pressure of 1.0 MPa. After manufacture, the panels were conditioned in a climate-controlled room at a temperature of $20+2{ }^{\circ} \mathrm{C}$ and relative humidity of $65+5 \%$ until reaching the equilibrium moisture content of $12 \%$. Then the panels were trimmed, sanded and test specimens were obtained according the specifications of the standard NBR CB 31 (ABNT, 2001).

\section{Plywood quality evaluation}

Water absorption

The water absorption evaluation was performed by immersing the test specimens in water at room temperature and measuring their weight after 2 and 24 hours, according to the procedures described in NBR-9486 (ABNT, 1986b).

\section{Mechanical properties}

The mechanical properties evaluated were glueline shear strength, Janka hardness and static bending, according the procedures of the respective ABNT standards, NBR 9534 (ABNT, 1986c), NBR 14810 (ABNT, 2006), NBR 9433/86 (ABNT, 1986a). From the static bending strength, modulus of elasticity (MOE) and modulus of rupture (MOR) were obtained.

\section{Statistical analysis}

All statistical analyses of the experimental data were carried out using the software BioStat. First, to check the normality and homogeneity of the data, the Shapiro-Wilk test was employed. When the experimental data had nonparametric distribution, the Kruskal-Wallis test was applied. For all cases, means from experimental treatments were compared using the Tukey test at $95 \%$ probability.

\section{Results and Discussion}

The condensed tannins content (Table 1) of the Acacia mangium bark was $13.5 \%$, below the values in the range of 30 to $47 \%$ reported in the literature for black wattle (Gujrathi \& Babu, 2007). Nevertheless, according to Paes et al. (2010), forest species with CTC higher than $10 \%$ in their bark or wood have potential for production of tannins, so considering that Acacia mangium is usually planted in Brazil for restoration of degraded areas and the only use for the trees after harvesting is as inexpensive firewood, previous debarking of the harvested trees for tannins production before their use for 
Table 1. Total solids content (TSC), Stiasny number (I) and condensed tannins content (CTC) determined for the Acacia mangium bark.

\begin{tabular}{ccc}
\hline \multicolumn{3}{c}{ Parameter (\%) } \\
\hline TSC & I & CTC \\
\hline 15.1 & 89.6 & 13.5 \\
\hline
\end{tabular}

energy generation can be an alternative to increase income per planted area. Assessing the bark of Anandenanthera colubrina (Vell.). Brenan., Paes et al. (2010) found a CTC equal to $13.95 \%$. Also, Azevêdo et al. (2017) determined CTC in the range of 16.04 to $21.90 \%$ for Mimosa tenuiflora (Mart.) Benth. bark. However, these native species, when used in forestation or reforestation, grow much slower than Acacia mangium, a factor to be considered in the choice of species to be employed for restoration of degraded areas. If the tannins production from the bark is added to the end uses of the wood, the investments can have excellent amortization rates.

\section{Properties of adhesives}

The adhesives' properties are displayed in Table 2 together with the statistical comparison for each property. Despite being projected to reach solids content of $50 \%$, the experimental value was $47.3 \%$ for the adhesive prepared with tannins from Acacia mangium bark. The commercial adhesives, tannin-based and phenol-formaldehyde, had solids contents of 46.0 and $52.3 \%$, respectively. These values are statistically different from each other, but as will be discussed shortly, the differences among the adhesives regarding solids content most likely are not directly related to variation in the bonding performance.

Using a similar method as ours, Carvalho et al. (2016) assessed an adhesive based on Acacia mangium bark tannins and found solids content of $47.9 \%$, which is very close to the value determined here. The solids content closely reflects the percentage of reactive material able to be crosslinked by formaldehyde, the linking agent.

However, the viscosity tends to increase undesirably as that property increases beyond a certain point, which can hamper the application of the adhesive by preventing both spreading and penetration into the wood structure. The higher value of solid contents observed for the phenol-formaldehyde adhesive can be considered normal and within standard values for this type of adhesive. Usually, the solids content of the adhesives employed in plywood bonding are around $48 \%$ for phenolics, 50 to $55 \%$ for urea-formaldehyde and $50 \%$ for tannin-based ones (Pizzi, 1994).
Likewise, the viscosity followed the same pattern observed in the statistical comparison of solids content, in ascending order of black wattle, Acacia mangium and phenolformaldehyde adhesives, with respective values of 663, 2,169 and 5,456 cP. Usually, as pointed out above, high viscosities are undesired for application of adhesive formulations (Mori et al., 2001) because of the weak glueline. Nevertheless, this pattern was not observed in the present work, even with the high values presented by the phenol-formaldehyde and black wattle adhesives. The adhesive from Acacia mangium bark had low viscosity in comparison with the commercial adhesives, which is interesting in terms industrial-scale production since no treatments to decrease this property (such as sulfitation) would be required.

Concerning gel time, according to Pizzi (1994) this property is a direct measure of the reactivity of the adhesive, which can result in lower pressing times at the same curing temperature. For this property, the adhesive based on black wattle tannins had the lowest value, of $135 \mathrm{~s}$, followed by Acacia mangium and phenol-formaldehyde with 240 and $787 \mathrm{~s}$, respectively. Although having the lowest viscosity of all, the black wattlebased adhesive was the most reactive. Regarding $\mathrm{pH}$, despite being statistically different, the values found for both tanninbased adhesives were distant from each other, with 4.18 and 5.60 for the adhesives from black wattle and Acacia mangium, respectively. The phenol-formaldehyde adhesive presented typical alkaline $\mathrm{pH}$. According to Zhang et al. (2010), the $\mathrm{pH}$ of adhesives for wood bonding should be carefully evaluated, since very acidic adhesives can create a corrosive environment along the glueline that might contribute to panel degradation.

\section{Plywood quality evaluation}

The shear strength assay has the goal of assessing the mechanical resistance of the glueline and consequently the bonding quality. As displayed in Table 3, there was no statistical difference among the three types of adhesives regarding the shear strength.

Even though the value found for the phenol-formaldehyde adhesive was higher than the others, there was no statistical difference among them, which is beneficial considering that in the formulation with Acacia mangium bark extract, the tannins were used without any type of chemical treatment after hot-water extraction. When performing mechanical assays with 3-ply panels bonded with adhesives based on tannins from Pinus oocarpa bark, Silva et al. (2012) found average value of $1.72 \mathrm{MPa}$ for shear strength, a result higher than that observed by us for the three types of adhesives. The

Table 2. Statistical comparison of adhesive properties.

\begin{tabular}{|c|c|c|c|c|c|c|c|c|}
\hline \multirow[b]{2}{*}{ Adhesive type } & \multicolumn{8}{|c|}{ Properties } \\
\hline & $\begin{array}{c}\text { Solids } \\
\text { content (\%) }\end{array}$ & $\begin{array}{l}\text { CV } \\
(\%)\end{array}$ & $\begin{array}{l}\text { Viscosity } \\
\text { (cP) }\end{array}$ & $\begin{array}{l}\text { CV } \\
(\%)\end{array}$ & $\begin{array}{l}\text { Gel time } \\
\text { (s) }\end{array}$ & $\begin{array}{l}\text { CV } \\
(\%)\end{array}$ & $\mathrm{pH}$ & $\begin{array}{l}\text { CV } \\
(\%)\end{array}$ \\
\hline Acacia mangium tannins & $47.3 \mathrm{~b}$ & 1.11 & $2,169 \mathrm{~b}$ & 17.09 & $240 \mathrm{~b}$ & 8.38 & $4.18 \mathrm{c}$ & 0.14 \\
\hline Phenol-formaldehyde & $52.6 \mathrm{a}$ & 0.86 & $5,456 \mathrm{a}$ & 18.23 & $787 \mathrm{a}$ & 5.20 & $12.20 \mathrm{a}$ & 2.08 \\
\hline
\end{tabular}

*Means in columns followed by different letters are statistically dissimilar by the Tukey test at $95 \%$ probability. 
Table 3. Statistical comparison of shear strength and Janka hardness of plywood panels bonded with three types of adhesives.

\begin{tabular}{ccccc}
\hline \multirow{2}{*}{ Adhesive } & \multicolumn{3}{c}{ Mechanical Property } \\
\cline { 2 - 5 } & $\begin{array}{c}\text { Shear strength } \\
(\mathrm{MPa})\end{array}$ & $\begin{array}{c}\text { CV } \\
(\%)\end{array}$ & $\begin{array}{c}\text { Janka Hardness } \\
\text { (MPa) }\end{array}$ & $\begin{array}{c}\text { CV } \\
\text { (\%) }\end{array}$ \\
\hline Acacia mangium tannins & $1.02 \mathrm{a}$ & 31.13 & $51.2 \mathrm{a}$ & 52.90 \\
Black wattle tannins & $1.01 \mathrm{a}$ & 21.34 & $35.5 \mathrm{a}$ & \\
Phenol-formaldehyde & $1.44 \mathrm{a}$ & 19.99 & $53.8 \mathrm{a}$ & 14.45 \\
\hline
\end{tabular}

*Means in columns followed by same letters are statistically equal by the Tukey test at $95 \%$ probability.

high coefficient of variation presented by the $A$. mangium tannin-based adhesive are likely related to the fact that the raw extract was employed directly for wood bonding without any adjustment or pretreatment. According to Pizzi (1994), to reach high-performance in wood bonding, the raw extract should be submitted to sulfitation or other treatments.

Analyzing adhesives made of black wattle tannins, Goulart et al. (2012) determined shear strength of 2.02 MPa. With tannins from Acacia mangium fortified with phenol-formaldehyde resins, Hoong et al. (2009) obtained shear strengths of 1.86 and $2.01 \mathrm{MPa}$, when 10 and $20 \%$ of the synthetic adhesive were added. Such differences of shear strength results mostly likely are due to differences of bonding conditions (pressing and gel time), type of wood and also assembly time. According to Lima et al. (2011), variations of these factors are decisive for the bonding performance and consequently the shear strength, with special consideration to the assembly and gel times (Nascimento et al., 2013).

However, all three adhesives tested here had shear strength compatible with values reported in the literature, higher than 1.0 $\mathrm{MPa}$, which is the minimum required by the European standard EN 314-2 (ECS, 1993) regardless of wood failure assessment. Table 3 also displays the mean values obtained for Janka hardness, which is an important property to define the final use of plywood panels. Hardness is of practical interest for hardboard, super hardboard and other panels, especially when they are used as flooring components. The hardness values obtained in the present work are in accordance with the values required for these types of products cited by Kollman et al. (2013).

Table 4 presents the values for perpendicular and parallelto-grain modulus of elasticity (MOE) and modulus of rupture (MOR) for plywood panels bonded with the three types of adhesives.

Concerning the static bending assay, panels bonded with adhesive based on Acacia mangium tannins performed better than that made from black wattle tannins and equal to the phenol-formaldehyde adhesive for perpendicular MOE and
MOR. The same pattern was observed for the parallel-to-grain MOE. However, there was no statistical difference among the three adhesives regarding the parallel-to-grain MOR. Indeed, for all perpendicular and parallel-to-grain MOE and MOR values, there was no statistical difference between the adhesives based on Acacia mangium tannins and the phenolformaldehyde formulation.

According to the experimental results, plywood bonded with Acacia mangium tannins were more rigid and less elastic than the panels bonded with the other adhesives. In a study carried out by Carvalho et al. (2016) to assess the bonding performance of natural and synthetic adhesives, the authors observed mean values of 20.91 and $38.17 \mathrm{MPa}$ for the perpendicular and parallel-to-grain MOR, respectively, for plywood bonded with Acacia mangium tannins. For the MOE, the values found by the same authors were 1,389 and 3,819 $\mathrm{MPa}$ in the perpendicular and parallel-to-grain directions, lower than those determined in the present work. In the same study, those authors assessed plywood panels bonded with adhesives based on tannins from Stryphnodendron adstringens (Mart.) Coville bark and found a value of 46.03 MPs for the parallel-to-grain MOR, which is lower than that found in the present work.

In an investigation of the quality of plywood panels manufactured with Pinus oocarpa Schiéde wood bonded with phenol-formaldehyde adhesive, Iwakiri et al. (2012) obtained values of perpendicular-to-grain MOE and MOR of 3,674 and $47,4 \mathrm{MPa}$, respectively, while for the same parallel-to-grain properties they found respective values of 7,079 and 61.7 $\mathrm{MPa}$. Those values are superior to those found in the present work. The difference might be related to the type of wood used or the bonding conditions.

Table 5 reports the values of water absorption after 2 and 24 hours for plywood panels bonded with the three types of adhesives.

After both immersion times, the percentage of water absorption was lower for the plywood panels bonded with the phenol-formaldehyde adhesive, followed by the formulations

Table 4. Statistical comparison of perpendicular and parallel-to-grain modulus of elasticity (MOE) and modulus of rupture (MOR) of plywood panels bonded with three types of adhesives.

\begin{tabular}{|c|c|c|c|c|c|c|c|c|}
\hline \multirow[b]{2}{*}{ Adhesive } & \multicolumn{4}{|c|}{ MOE (MPa) } & \multicolumn{4}{|c|}{ MOR (MPa) } \\
\hline & $90^{\circ}$-to-grain & $\begin{array}{l}\text { CV } \\
\text { (\%) }\end{array}$ & $0^{\circ}$-to-grain & $\begin{array}{l}\text { CV } \\
(\%)\end{array}$ & $90^{\circ}$-to-grain & $\begin{array}{l}\text { CV } \\
(\%)\end{array}$ & $0^{\circ}$-to-grain & $\begin{array}{l}\text { CV } \\
\text { (\%) }\end{array}$ \\
\hline Acacia mangium tannins & $1,836 \mathrm{a}$ & 37.41 & $6,539 a$ & 34.85 & $32.7 \mathrm{a}$ & 33.67 & $59.4 \mathrm{a}$ & 18.68 \\
\hline Black wattle tannins & $1,234 \mathrm{~b}$ & 14.14 & $3,039 b$ & 27.86 & $20.0 \mathrm{~b}$ & 18.58 & $37.4 \mathrm{a}$ & 51.10 \\
\hline Phenol-formaldehyde & $1,362 a b$ & 4.09 & $3,777 \mathrm{ab}$ & 28.97 & $25.3 \mathrm{ab}$ & 14.07 & $39.9 a$ & 32.76 \\
\hline
\end{tabular}

${ }^{*}$ Means in columns followed by different letters are statistically dissimilar by the Tukey test at $95 \%$ probability. 
Table 5. Statistical comparison of water absorption after 2 and 24 hours for plywood panels bonded with three types of adhesives.

\begin{tabular}{lcccc}
\hline \multirow{2}{*}{\multicolumn{1}{c}{ Adhesive }} & \multicolumn{4}{c}{ Water absorption (\%) } \\
\cline { 2 - 5 } & $\mathbf{2}$ & $\mathbf{C V}$ & $\mathbf{2 4}$ & $\mathbf{C V}$ \\
& hours & $\mathbf{( \% )}$ & hours & (\%) \\
\hline Acacia mangium tannins & $59.6 \mathrm{a}$ & 23.50 & $83.1 \mathrm{a}$ & 53.85 \\
\hline Black wattle tannins & $52.2 \mathrm{a}$ & 26.69 & $79.3 \mathrm{a}$ & 16.61 \\
\hline Phenol-formaldehyde & $45.4 \mathrm{a}$ & 8.76 & $58.4 \mathrm{a}$ & 10.29 \\
\hline
\end{tabular}

*Means in columns followed by different letters are statistically dissimilar by the Tukey test at $95 \%$ probability.

with black wattle and Acacia mangium tannins. Despite this trend, there was no statistically significant difference among the three types of adhesives for both water absorption times. The higher values of water absorption observed for tanninbased adhesives can be attributed to the higher amount of hydroxyl groups per molecule, which makes the hydrophilic character of the formulations stronger.

Carrying out water absorption assays with panels bonded with adhesives based on black wattle tannins, Carvalho et al. (2016) determined values of $91.4 \%$ after 2 hours of immersion, significantly higher than the value found in this work for the adhesive based on tannins from Acacia mangium bark. The water absorption of the latter adhesive is coherent with the values found in the literature.

\section{Conclusions}

The yield of condensed tannins from the Acacia mangium bark was less than $50 \%$ of that usually cited for black wattle bark.

Considering that Acacia mangium is extensively planted in Northeastern Brazil for restoration of degraded areas, and the only economic use of the wood after harvesting is firewood, further research should evaluate whether prior debarking of the logs is an alternative to add value to the trees.

The crude hot-water extract of Acacia mangium bark was employed to produce adhesive without any chemical modification.

Regarding mechanical properties, the use of the adhesive based on tannins from the bark of Acacia mangium trees grown in Northeastern Brazil presented acceptable performance for plywood bonding, with quality similar to or better than adhesives made with black wattle tannins and phenol-formaldehyde.

However, when water absorption of the produced panels is considered, the plywood bonded with Acacia mangium tannins are suitable only for indoor uses.

\section{Acknowledgments}

This study was financed in part by the Office to Coordinate Improvement of University Personnel (CAPES), Finance Code 001. We are grateful to Federal University of Lavras (UFLA) for providing financial support, laboratories and facilities, and to the National Council for Scientific and Technological
Development (CNPq) for the research grant and students' scholarships.

\section{Literature Cited}

American Society for Testing and Materials - ASTM. ASTM D108497. Standard test methods for viscosity of adhesives. West Conshohocken: ASTM International, 1997. 5p.

American Society for Testing and Materials - ASTM. ASTM D149001. Standard test method for nonvolatile content of ureaformaldehyde resin solutions. West Conshohocken: ASTM International, 2006. 2p.

Araújo, J. S. C.; Castilho, A. R. F; Lira, A. B.; Pereira, A. V.; Azevêdo, T. K. B.; Costa, E. M. M. B.; Pereira, M. S. D. V.; Pessoa, H. L. F.; Pereira, J. V. Antibacterial activity against cariogenic bacteria and cytotoxic and genotoxic potential of Anacardium occidentale L. and Anadenanthera macrocarpa (Benth.) Brenan extracts. Archives of Oral Biology, v.85, n.8, p.113-119, 2018. https://doi. org/10.1016/j.archoralbio.2017.10.008.

Associação Brasileira de Normas Técnicas - ABNT. (2006) NBR 148103: chapas de madeira aglomerada - parte 3 - métodos de Ensaio. Rio de Janeiro: ABNT, 2006.

Associação Brasileira de Normas Técnicas - ABNT. NBR CB-31: projeto de normas 31.000.05.001/1: chapas de madeira compensada. Rio de Janeiro: ABNT, 2001.

Associação Brasileira de Normas Técnicas - ABNT. NBR-9433: Painéis de madeira compensada - determinação dos módulos de elasticidade em resistência à flexão. Rio de Janeiro: ABNT, 1986a.

Associação Brasileira de Normas Técnicas - ABNT. NBR-9486: Painéis de madeira compensada - determinação da absorção de água. Rio de Janeiro: ABNT, 1986b.

Associação Brasileira de Normas Técnicas - ABNT. NBR-9534: Painéis de madeira compensada - determinação da resistência da colagem ao esforço de cisalhamento. Rio de Janeiro: ABNT, 1986c.

Azevêdo, T. K. B.; Paes, J. B.; Calegari, L.; Santana, G. M. Teor de taninos condensados presente na casca de Jurema-preta (Mimosa tenuiflora) em função das fenofases. Floresta e Ambiente, v.24, e00026613, 2017. https://doi.org/10.1590/2179-8087.026613.

Balieiro, F.C.; Dias, L.E.; Franco, A.A.; Campello, E.F.C.; Faria, S.M. Acúmulo de nutrientes na parte aérea, na serapilheira acumulada sobre o solo e decomposição de filódios de Acacia mangium Willd. Ciência Florestal, v.14, n.1, p.59-65, 2004. https://doi. org/10.5902/198050981781.

Carvalho, A. G.; Zanuncio, A. J. V.; Mori, F. A.; Mendes, R. F.; Mendes, L. M. Adesivos naturais e sintéticos em painéis compensados. Ciência da Madeira, v.7, n.1, p.28-35, 2016. https://doi. org/10.12953/2177-6830/rcm.v7n1p28-35.

Carvalho, R. S.; Carollo, C. A.; Magalhães, J. C.; Palumbo, J. M. C.; Boaretto, A. G.; S, I. C. N.; Ferraz, A. C.; Lima, W. G.; Siqueira, J. M.; Ferreira, J. M. S.; Antibacterial and antifungal activities of phenolic compound-enriched ethyl acetate fraction from Cochlospermum regium (mart. Et. Schr.) pilger roots: mechanisms of action and synergism with tannin and gallic acid. South African Journal of Botany, v.114, p.181-187, 2018. https://doi.org/10.1016/j. sajb.2017.11.010. 
Chan, J.M.; Day, P.; Feely, J.; Thompson, R.; Little, K.M.; Norris, C.H. Acacia mearnsii industry overview: current status, key research and development issues, Southern Forests: a Journal of Forest Science, v.77, n.1, p.19-30, 2015. https://doi.org/10.2989/2070 2620.2015.1006907.

Durval, A.; Couture, G.; Cailol, S.; Ayérous, L. Biobased and aromatic reversible thermoset networks from condensed tannins via the diels-alder reaction. ACS Sustainable Chemistry \& Engineering, v.5, n.1, p.1199-1207, 2017. https://doi.org/10.1021/ acssuschemeng.6b02596.

European Committee for Standardization - ECS. EN 314-2 - Plywoodbonding quality-Part 2: requirements. Brussels: ECS, 1993.

Goulart, S. L.; Mori, F. A.; Almeida, N.F.; Mendes, R. F.; Mendes, L. M. Resistência ao cisalhamento de painéis compensados produzidos com adesivo à base de taninos de Stryphnodendron adstringens (barbatimão). Floresta e Ambiente, v.19, n.3, p.308-315, 2012. http://dx.doi.org/10.4322/floram.2012.036.

Guangcheng, Z.; Yunly, L.; Yazaki, Y. Extractive yields, Stiasny values and polyflavonoid content in barks from six acacia species in Australia. Australian Forestry, v. 54, n.3, p. 154-156, 1991. https://doi.org/10.1080/00049158.1991.10674572.

Gujrathi, A. M.; Babu, B. V. Environment friendly products from black wattle. Energy Education Science and Technology, v.19, n.1, p.3744, 2007.https://www.researchgate.net/publication/228652682. 13 May. 2020.

Hillig, E.; Haselein, C. R.; Santini, E. J.; Propriedades mecânicas de chapas aglomeradas estruturais fabricadas com madeiras de pinus, eucalipto e acácia-negra. Ciência Florestal, v.12, n.1, p.5970, 2002. https://doi.org/10.5902/198050981701.

Hoong, Y. B.; Paridah, T.; Loh, Y. F.; Jalaluddin, H.; Chuah, L. A. A new source of natural adhesive: Acacia mangium bark extracts co-polymerized with phenol-formadehyde (PF) for bonding mempisang (Annonaceae spp.) veneers. International Journal of Adhesion and Adhesives, v.31, n.3, p.164-167, 2011. https://doi. org/10.1016/j.ijadhadh.2010.12.002.

Hoong, Y. B.; Paridaha, M. T.; Luqmanb, C. A.; Kohc, M. P.; Lohd, Y. F. Fortification of sulfited tannin from the bark of Acacia mangium with phenol-formaldehyde for use as plywood adhesive. Industrial Crops and Products, v.30, n.3, p.416-421, 2009. https:// doi.org/10.1016/j.indcrop.2009.07.012.

Instituto de Desenvolvimento Econômico e Meio Ambiente do Rio Grande do Norte - IDEMA. Perfil do seu município: Macaíba. Natal: IDEMA, 2013. 23p. http://adcon.rn.gov.br/ACERVO/ idema/DOC/DOC000000000016679.PDF. 29 Mar. 2020.

Instituto de Pesquisas e Estudos Florestais - IPEF. Identificação de espécies florestais. Acacia mangium (Acácia). https://www2.ipef. br/identificacao/acacia.mangium.asp. 19 Mar. 2020.
Iwakiri, S.; Manhiça, A. A.; Ramirez, M. G. L.; Matos, J. L. M.; Bonduelle, G. M.; Prata, J. G. Avaliação da qualidade de painéis compensados de Pinus maximinoi, Pinus oocarpa e Pinus tecunumannii com diferentes composições estruturais. Ciência Florestal, v.22, n.2, p.315-321, 2012. https://doi.org/10.5902/198050985738.

Kollman, F. F. P.; Kuenzi, A.; Stamm, A. J. Principles of wood science and technology: II wood-based materials. 2.ed. Berlin: SpringerVerlag, 2013. 703p.

Lima, N. N.; Pio, N. S.; Cunha, U. S.; Lucas Filho, F. C.; Barbosa Filho, J. Influência da gramatura na resistência da linha de cola aos esforços de cisalhamento em painéis compensados de Copaifera duckei Dawyer e Eperua oleifera Ducke. Acta Amazonica, v.41, n.1, p.8390, 2011. https://doi.org/10.1590/S0044-59672011000100010.

Mori, F. A.; Vital, B. R.; Pimenta, A. S.; Ferraz, V. P. Estudo de taninos da casca de Eucalyptus urophylla S.T. Blake para produção de adesivos. Revista Árvore, v. 25, n. 2, p.257-263, 2001.

Nascimento, A. M.; Garcia, R. A.; Della Lucia, R. M. Qualidade de adesão de juntas coladas de diferentes espécies comerciais de madeira. Cerne, v. 19, n. 4, p. 593-601, 2013. https://doi. org/10.1590/S0104-77602013000400009.

Nepomuceno, T. C.; Ferreira, W. B.; Paiva, W.; Diniz, T. R; Santos, W. B. Aplicabilidade de coagulantes a base de tanino em estações de tratamento de água. Revista Ibero-Americana de Ciências Ambientais, v. 9, n. 7, p.110-123, 2018. https://doi.org/10.6008/ CBPC2179-6858.2018.007.0011.

Özbay, G.; Ayrilmis, N. Bonding performance of wood bonded with adhesive mixtures composed of phenol-formaldehyde and biooil. Industrial Crops and Products; v.66, p.68-72, 2015. https:// doi.org/10.1016/j.indcrop.2014.12.028.

Paes, J. B.; Santana, G. M.; Azevedo, T. K. B.; Morais, R. M.; Calixto, J. T. $J R$. Substâncias tânicas presentes em várias partes da árvore angicovermelho (Anadenanthera colubrina (Vell.) Brenan. var. cebil (Gris.) Alts.). Scientia Forestalis, v.38, n.87, p.441-447, 2010. https://www. ipef.br/publicacoes/scientia/nr87/cap11.pdf. 29 Mar. 2020.

Pizzi, A. Advances wood adhesives technology. New York: Marcel Dekker, 1994. Chap. 5, p.149-218.

Silva, B. C.; Vieira, M. C.; Oliveira, G. L.; Gonçalves, F. G.; Rodrigues, N. D.; Lelis, R. C.; Iwakiri, S. Qualidade de compensados fabricados com adesivos à base de tanino-formaldeído de Pinus oocarpa e fenol-formaldeído. Floresta e Ambiente, v.19, n.4, p.511-519, 2012. https://doi.org/10.4322/floram.2012.057.

Zhang, Z.; Wang, X. M.; Casilla, R.; Cooper, P.; Huang, Z.; Wang, X. Impact of curing condition on $\mathrm{pH}$ and alkalinity of structural wood adhesives. Journal of Applied Polymer Science, v. 117, n.5, p. 2888-2898, 2010. https://doi.org/10.1002/app.32201.

Zhou, X.; Pizzi, A. Pine tannin adhesives for plywood. International Wood Products Journal, v.5, n.1, p.27-32, 2014. https://doi.org/1 $0.1179 / 2042645313$ Y.0000000043. 